\title{
SIBLING RIVALRY ANTARA ANAK DENGAN MILD INTELLECTUAL DISABILITY DAN SAUDARA KANDUNG
}

\author{
Nago Tejena dan Tience Debora Valentina
}

Program Studi Psikologi, Fakultas Kedokteran, Universitas Udayana

nagotejena@gmail.com

\begin{abstract}
Abstrak
Manusia tumbuh dan berkembang sepanjang hidupnya. Terdapat beberapa faktor yang mempengaruhi perkembangan seorang manusia. Ketika terjadi gangguan pada faktor-faktor ini, maka akan muncul hambatan perkembangan pada diri anak, salah satunya adalah intellectual disability. Anak intellectual disability memerlukan perhatian lebih dari keluarga. Hal ini akan memicu perebutan sumber daya antara anak dengan intellectual disability dan saudaranya. Perebutan ini akan menimbulkan konflik diantara mereka, yang mengarah pada sibling rivalry. Tujuan dari penelitian ini adalah untuk mengetahui dinamika sibling rivalry pada anak dengan mild intellectual disability dan saudara kandung.

Penelitian kualitatif ini menggunakan pendekatan studi kasus.Teknik pengambilan sampel yang digunakan adalah purposive sampling. Subjek dalam penelitian ini adalah seorang anak berusia 11 tahun dengan mild intellectual disability, dan memiliki dua orang saudara kandung. Teknik penggalian data yang digunakan adalah observasi, wawancara, catatan lapangan dan rekaman audio visual. Data yang terkumpul dianalisis menggunakan teknik pengorganisasian data kualitatif pendekatan studi kasus menurut Cresswell (1998).

Berdasarkan hasil pengorganisasian data, ditemukan 33 kategori yang dapat dikelompokkan menjadi 6 pola. Polapola tersebut adalah 1) faktor-faktor sibling rivalry; 2) pemicu pertengkaran; 3) sibling rivalry; 4) cara penyelesaian masalah ketika terjadi konflik; 5) setelah pertengkaran selesai; dan 6) sudut pandang antara subjek dan saudaranya.

Kata kunci : sibling rivalry, mild intellectual disability, anak.
\end{abstract}

\begin{abstract}
Human grow and develop throughout their life. There are several factors that influence human development. When there is an interference on these factors, it will cause developmental delays in children, such as intellectual disability. Children with intellectual disability require extra attention from the family. This will trigger a fight for resources between children with intellectual disability and their siblings. This situation will create conflict between them, which leads to sibling rivalry. The aim of this study is to determine the dynamics of sibling rivalry between child with mild intellectual disability and her siblings.

This qualitative research is designed with case study approach. Sampling technique used is purposive sampling. Subject of this study is an 11 years old child with mild intellectual disability, who has two siblings. Data collecting techniques used are observation, interview, field note and audio- visual recording. The data were analyzed using data organization technique for qualitative study with case study approach according to Cresswell (1998).

Based on the results from data organization, this study found 33 categories that can be grouped into 6 patterns. The patterns are 1) sibling rivalry factors; 2) fight's trigger; 3) types of sibling rivalry; 4) problem solving method when there is a conflict; 5) situation after the fight finished; and 6) the differences of point of view between subject and her siblings.
\end{abstract}

Keywords : sibling rivalry, mild intellectual disability, child. 


\section{LATAR BELAKANG}

Manusia tumbuh dan berkembang sepanjang hidupnya. Diyakini, masa perkembangan saat individu kanakkanak merupakan hal yang akan berpengaruh pada kehidupannya ketika individu akan dewasa nantinya. Ada banyak faktor yang dapat mempengaruhi bagaimana individu berkembang ataupun melewati perkembangannya pada saat masih di usia kanak - kanak. Menurut Fatimah (2012), faktorfaktor ini dapat berupa genetik, hormon, gizi, lingkungan, pengetahuan keluarga sampai dengan kebudayaan setempat. Faktor-faktor inilah yang akan membentuk individu pada saat fase kanak-kanak, dan menentukan perkembangannya sampai pada fase dewasa. Woodruff, dkk. (dalam Papalia, dkk., 2009) mengatakan bahwa bila seorang anak memiliki gangguan genetik, trauma pada saat masa kecil, penyakit yang membahayakan nyawa, ataupun gangguan lain dalam memenuhi kebutuhan perkembangannya, dapat menyebabkan anak tersebut mengalami gangguan perkembangan, salah satunya adalah intellectual disability.

Intellectual disability merupakan keadaan fungsi kemampuan intelegensi yang nilainya berada di bawah ratarata secara signifikan (APA, 2000). Di Indonesia, 1-3\% penduduknya mengalami intellectual disability (Maulina \& Sutatminingsih, 2005). Rasio terjadinya intellectual disability antara laki-laki dan perempuan adalah $3: 2$. Terbukti bahwa laki-laki lebih rawan terkena gangguan perkembangan intellectual disability ketimbang perempuan pada umumnya (Maulina \& Sutatminingsih, 2005). Menurut Kementerian Pendidikan Nasional Republik Indonesia intellectual disability merupakan suatu fenomena yang sudah menjamur di Indonesia, dilaporkan bahwa 1.460 .333 anak di Indonesia memiliki intellectual disability (Wahab, 2005). Terdapat 4 kategori yang membagi intellectual disability menurut rentang keparahan dari intellectual disability sendiri. Tingkatan intellectual disability dibagi menjadi Mild, Moderate, Severe, dan Profound. Dari masing-masing tingkatan terdapat karakteristik yang berbeda-beda secara kemampuan intelektual, kemampuan berkomunikasi, serta kemampuan adaptif dalam kehidupan sehari-hari.

Anak dengan intellectual disability memerlukan bantuan serta dukungan agar dapat menjalani aktivitas seharihari dengan baik. Bantuan dan dukungan ini tak lepas dari faktor keberadaan keluarga. Orangtua perlu untuk memberikan perhatian, kekompakan dalam mengasuh, menumbuhkan kepercayaan diri pada anak, serta keikhlasan dalam merawat anak dengan intellectual disability. Harapannya, anak dengan intellectual disability mendapatkan dukungan penuh dari orangtua guna menyokong kebutuhan perkembangannya yang terhambat (Gralfitrisia, 2012).

Dalam sebuah keluarga, di samping orangtua, keberadaan dari saudara kandung merupakan salah satu aspek yang tidak dapat dilewatkan. Jika orangtua lebih banyak memberikan waktu berbentuk afeksi, perhatian, maupun perawatan pada salah satu anak, akan memicu perasaan negatif pada saudaranya yang tidak mendapat perhatian sebanyak itu. Perlakuan ini akan menimbulkan kecemburuan, mempengaruhi hubungan kedekatan, dan mempengaruhi harga diri pada anak tersebut (Rauer \& Volling, 2007). Pada satu sisi, dengan kondisi orangtua yang cenderung memberikan perhatian lebih banyak pada salah satu anak, saudara kandung dapat dinilai sebagai seorang pesaing dalam memanfaatkan sumber daya yang didapat dari orangtua. Hal ini akan menimbulkan konflik serta hubungan negatif antar saudara dan memicu sibling rivalry.

Sibling rivalry merupakan bentuk kompetisi ataupun dendam antar saudara, baik sedarah maupun tidak (Leder, 2004). Sibling rivalry pada dasarnya hanya didasari oleh satu alasan utama, yakni sumber daya yang langka. Sumber daya yang minim, harus dibagi oleh anak - anak yang ada dalam keluarga tersebut. Sumber daya dapat berupa makanan, mainan, maupun kasih sayang serta penerimaan orangtua. Ketika sumber daya ini tidak dapat terbagi maupun dibagi secara adil oleh orangtua, akan muncul berbagai konflik pada anak dan saudara. Konflik yang tidak diselesaikan akan menimbulkan sibling rivalry (Boyle, 2011).

Terdapat 3 bentuk dari sibling rivalry (Sawicki, 1997), antara lain agresi, regresi, maupun rivalry. Agresi sendiri berarti munculnya perilaku agresif baik verbal maupun non-verbal, regresi berarti kemunduran tingkah laku yang sudah dikuasai, serta rivalry yang berarti munculnya perasaan seperti iri, cemburu dan depresi karena adanya persaingan.

Rimm (2002) mengatakan bahwa sibling rivalry cenderung muncul pada saudara yang memiliki tingkat inteligensi lebih tinggi, atau gifted. Hal ini menunjukkan bahwa kesenjangan diantara saudara menjadi salah satu pemicu munculnya konflik atau persaingan. Meski demikian, Weiss (2013) menemukan bahwa sibling rivalry tidak terbatas hanya muncul pada individu normal saja. Kondisi ini akan muncul pada individu dengan keterbatasan - keterbatasan tertentu pula, dikarenakan kebutuhan yang perlu mereka penuhi. Fenomena munculnya konflik saudara dengan salah satu saudaranya berkebutuhan khusus sudah banyak bermunculan. Gardner (2007) mengatakan bahwa tindakan agresif dan mengganggu merupakan perilaku yang paling sering muncul pada anak dengan intellectual disability. Perilaku agresif ini dapat berupa kekerasan secara fisik dan verbal, kerap kali ditujukan pada keluarga, baik orangtua maupun saudara.

Saudara kandung akan mengalami berbagai macam perasaan yang berbeda terkait menanggapi perbedaan antara dirinya dan saudaranya yang memiliki kebutuhan khusus (Rabiner dalam Batt, 2010). Saudara kandung diberi ekpektasi oleh orangtua sebagai penjaga maupun merawat saudara dengan intellectual disability. Akan 
tetapi, tak jarang justru saudara kandung ini menjadi korban agresi saudara dengan intellectual disability. Berbagai bentuk agresi ditemukan muncul, dari verbal maupun fisik, dan kebanyakan saudara kandung merespon perlakuan ini dengan membalas balik. Muncul perasaan sedih dan kehilangan pada diri saudara kandung, disamping perasaan ketidakmampuan mereka untuk memiliki kehidupan yang normal. Hal ini akan memicu hubungan yang buruk antar saudara, dendam dan kompetisi yang menimbulkan sibling rivalry. (Rabiner, 2006). Berdasarkan uraian di atas, didapat bahwa sibling rivalry ternyata muncul pada anak dengan intellectual disability dengan saudara kandungnya. Berdasarkan paparan diatas, peneliti tertarik untuk melakukan penelitian tentang sibling rivalry pada anak dengan mild intellectual disability dan saudara kandung. Peneliti memilih anak yang memiliki intellectual disability dengan klasifikasi mild karena karakteristik yang dimiliki. Anak dengan mild intellectual disability masih dapat berkomunikasi secara baik dengan lingkungan di sekitarnya.

Penelitian ini bertujuan untuk mengetahui dinamika sibling rivalry yang muncul pada anak dengan mild intellectual disability dan saudara kandung. Hasilnya diharapkan dapat memberi sumbangan dan kontribusi dalam perkembangan keilmuan psikologi perkembangan, klinis, serta psikologi keluarga. Selain itu diharapkan juga dapat memberikan pengetahuan dan kesadaran pada keluarga responden penelitian ini tentang sibling rivalry yang terjadi.

\section{METODE}

\section{Pendekatan}

Penelitian ini merupakan penelitian kualitatif, yang menggunakan pendekatan studi kasus. Penelitian kualitatif merupakan sebuah penelitian yang tidak terikat akan angka dan perhitungan. Menurut Cresswell (1998), studi kasus merupakan eksplorasi dari sebuah sistem yang dibatasi, atau sebuah kasus (atau berbagai kasus) dari waktu ke waktu melalui pengumpulan data yang detail dan mendalam, serta melibatkan sumber informasi yang kaya akan konteks. Penting bagi peneliti untuk memiliki materi konteksual yang tersedia untuk menjelaskan suatu kasus.

\section{Kriteria Responden}

Adapun kategori subjek yang diperlukan dalam penelitian ini, yakni :

a. Anak dengan mild intellectual disability (Usia 9-12 tahun)

b. Memiliki orangtua

c.Memiliki saudara lebih dari 1 dengan rentang umur maksimal 3 tahun

d. Jenis kelamin subjek dan saudaranya sama

\section{e. Berdomisili di Denpasar}

Dalam proses pencarian sampelnya, peneliti menggunakan purposive sampling. Purposive sampling merupakan teknik pengambilan sampel yang berlandaskan tentang tujuan penelitian. Berikut tabel yang berisikan data dari keluarga subjek :

\begin{tabular}{|c|c|c|c|}
\hline Kode & Usia & Pendidikan & Keterangan \\
\hline A & 44 Tahun & S1-Ekonomi & Ayah \\
\hline I & 45 Tahun & SMEA & Ibu \\
\hline S1 & 13 Tahun & SMP (kelas 1) & Saudara 1 (kakak) \\
\hline Subjek & 11 Tahun & SLB-C (kelas 5) & Anak dengan Mild Intellectual Disability \\
\hline S2 & 8 Tahun & SD (kelas 2) & Saudara 2 (adik) \\
\hline
\end{tabular}

\section{Setting Penelitian}

Penelitian ini berlangsung di rumah subjek, yang beralamatkan di Jalan Tegalwangi, Sidakarya. Rumah subjek memiliki 2 tingkat, 2 ruangan di lantai 1, serta 3 ruangan di lantai 2. Peneliti berkunjung ke rumah subjek sebanyak 12 kali, dan mengambil rentang waktu sekitar 2 bulan. Dalam 1 minggu, frekuensi peneliti mengunjungi rumah subjek bervariasi dari 1 sampai 3 kali dalam seminggu. Kegiatan yang dilakukan peneliti ketika berkunjung dibagi atas perkenalan sebanyak 2 kali kunjungan, wawancara sebanyak 4 kali kunjungan, serta observasi sebanyak 6 kali kunjungan. Waktu yang biasanya diambil peneliti untuk mengambil data dari pukul 16.00 sampai dengan 18.00.

\section{Teknik Pengumpulan Data}

Dalam penelitian ini, peneliti menggunakan teknik observasi dan wawancara. Selain itu, ditambah pula dengan catatan lapangan dan rekaman audio-visual agar tidak melupakan fakta-fakta penting terkait penelitian.

1. Observasi.

Observasi adalah kegiatan memperhatikan secara akurat, mencatat fenomena yang muncul dan mempertimbangkan hubungan antar aspek dalam fenomena tersebut. Peneliti dalam penelitian ini menggunakan participant observation, hal ini dilakukan agar peneliti dapat memahami dengan baik kejadian maupun fenomena yang terjadi pada subjek secara natural pada situasi tertentu dan mengatasi keterbatasan waktu bersama.

\section{Wawancara}

Wawancara adalah percakapan dengan maksud tertentu (Moleong, 2004). Penelitian ini menggunakan kombinasi antara wawancara terstruktur dan wawancara tidak terstruktur. Wawancara terstruktur peneliti gunakan untuk mengetahui poin-poin maupun aspek-aspek penting yang diperlukan di penelitian ini. Sementara wawancara tidak terstruktur dilakukan jika ada temuan-temuan yang tidak direncanakan dan dianggap menarik untuk dieksplorasi secara lanjut dan fleksibel.

\section{Catatan Lapangan}


Catatan lapangan merupakan versi lengkap dari catatan apa yang dilihat, didengar, dirasakan, dicium, dan diraba peneliti pada saat melakukan kunjungan di lapangan (Moleong, 2004). Pada penelitian ini, selama proses observasi dan wawancara berlangsung, ketika peneliti menemukan fakta menarik maka peneliti akan mencatatnya di lembaran kertas yang dibawa. Setelahnya, jika data tersebut dirasa penting dalam menambah data dalam penelitian maka peneliti menggunakan catatan lapangan untuk melengkapi kembali data wawancara dan observasi yang diperoleh.

4. Rekaman Audio-Visual

Menurut Cresswell (1998), penelitian studi kasus memerlukan berbagai sumber informasi yang tersedia, salah satunya adalah bukti fisik. Peneliti menggunakan rekaman audio-visual sebagai bukti fisik dari kasus yang sedang dikaji. Rekaman disini dilakukan saat observasi, sehingga selain mendapatkan bukti fisik dari kasus, peneliti juga menggunakan rekaman audio-visual ini untuk memastikan bahwa tidak ada bukti yang terlewat. Peneliti menggunakan kamera pocket dalam melakukan rekaman audio-visual.

\section{Analisis data}

Stake dalam Cresswell (1998) mengungkapkan bahwa ada 4 bentuk analisis dan interpretasi data dalam penelitian studi kasus. Dalam Categorical Aggregation (Pengumpulan Kategori), peneliti berusaha untuk menarik instansi dari suatu data, sehingga peneliti data mengumpulkan dan menyatukan nilai-nilai dari suatu data yang terhubung dalam satu kategori. Selanjutnya terdapat Direct Interpretation (Interpretasi langsung), setelah didapat kategori, maka peneliti akan menarik arti dari kategori tersebut secara langsung tanpa terpengaruh dari kategori lainnya. Berlanjut ke proses Pattern (Pola), peneliti akan menarik korespondensi dari dua kategori atau lebih sehingga memasukkannya kepada suatu pola tertentu. Akhirnya, peneliti akan mengembangkan Naturalistic Generalizations (Generalisasi Natural), sehingga seseorang akan dapat belajar dari kasus ini baik untuk diri mereka sendiri maupun diterapkan pada populasi kasus yang dikaji.

Teknik Triangulasi

Triangulasi data adalah teknik pemeriksaan keabsahan data yang memanfaatkan sesuatu yang lain di luar data yang didapat, untuk keperluan pengecekan atau sebagai pembanding terhadap data tersebut. Denzin (dalam Moleong, 2004) membedakan empat macam triangulasi sebagai teknik pemeriksaan yang memanfaatkan penggunaan sumber, metode, penyidik, dan teori. Penelitian ini menggunakan triangulasi dengan sumber dan teori.

Triangulasi dengan sumber berarti membandingkan dan mengecek balik derajat kepercayaan suatu informasi yang diperoleh melalui waktu dan alat yang berbeda dalam penelitian kualitatif (Patton dalam Moleong, 2004). Pada penelitian ini, dilakukan perbandingan antara hasil observasi dengan hasil wawancara untuk memeriksa keabsahan data yang didapat. Selain itu peneliti juga melakukan triangulasi sumber dengan cara mengambil data pre-eliminary. Data yang diambil didapat melalui sumber yang berbeda, namun memiliki karakteristik sama dengan subjek yang telah ditentukan oleh peneliti.

Menurut Lincoln dan Guba (dalam Moleong, 2004), triangulasi dengan teori didasari anggapan bahwa fakta tidak dapat diperiksa derajat kepercayaannya dengan satu atau lebih teori. Maka penting sekali untuk mencari tema atau penjelasan lain sebagai pembanding. Pada penelitian ini, telah ditambahkan berbagai jenis teori lain di bagian pembahasan untuk membandingkan temuan yang sudah diperoleh peneliti dengan teori maupun temuan lain sebagai pembanding.

\section{Etika Penelitian}

Terdapat beberapa isu etik yang perlu diperhatikan dalam penelitian ini. Sebelum penelitian dimulai, peneliti harus memberikan penjelasan tentang tujuan dan proses penelitian ini kepada subjek dan keluarganya. Sementara dalam menggali data, peneliti diharapkan untuk dapat memahami situasi lingkungan subjek terkait dengan aspek seperti isu-isu sensitif dan sopan santun. Aspek kerahasiaan dalam penelitian ini juga perlu dijelaskan kepada subjek oleh peneliti, sehingga subjek beserta keluarganya dapat merasa aman. Jika dalam suatu keadaan subjek merasa tidak nyaman akan keberlangsungan penelitian ini, subjek dapat membatalkan kesediaannya sebagai subjek. Seluruh infomasi mengenai isu etik ini diberikan dalam bentuk inform consent dan disetujui bersama dengan menandatangani surat persetujuan.

\section{HASIL PENELITIAN}

Dalam penelitian ini, peneliti menemukan terdapat 33 jenis kategori yang berkaitan dengan sibling rivalry pada anak dengan mild intellectual disability dan saudara kandung. Kategori-kategori ini dikelompokkan berdasarkan kombinasi hasil dari wawancara dan observasi yang peneliti lakukan selama penelitian berlangsung. 33 Jenis kategori tersebut kemudian membentuk 6 pola dalam penelitian ini. Berikut hasil penyusunan 6 pola beserta 33 kategori tersebut : 


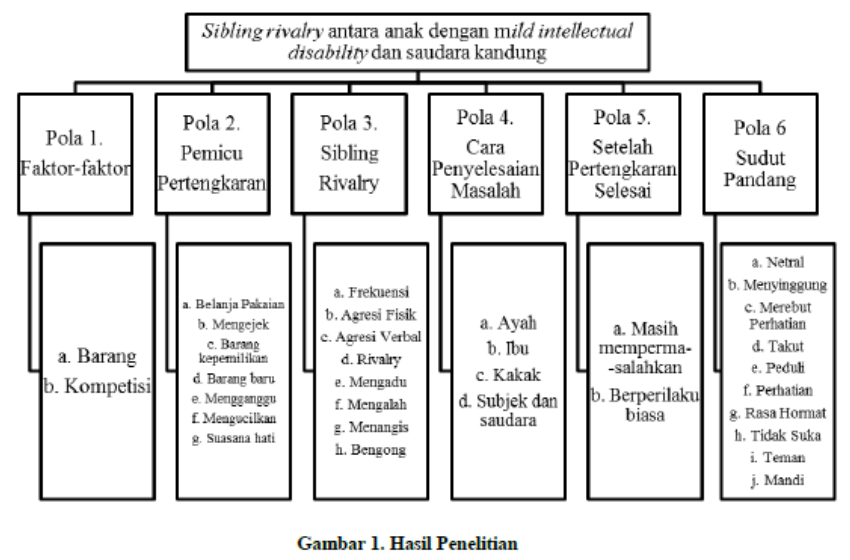

Pola 1. Faktor-faktor sibling rivalry (P1)

a. Subjek dan saudaranya bertengkar memperebutkan berbagai jenis barang seperti uang, alat tulis, pakaian, dan remote TV. (P1.Ka)

b. Subjek dan saudaranya berkompetisi dalam perlombaan makan, olahraga, dan memperebutkan perhatian orang di sekitarnya. (P1.Kb)

\section{Pola 2. Pemicu Pertengkaran (P2)}

a. Ketika ingin berbelanja, kakak dan adik subjek menunjukkan keinginan mereka untuk membeli dan lebih terencana. Muncul rasa iri hati pada subjek ketika melihat kakak dan adiknya membeli barang saat berbelanja. Hal ini membuat subjek menuntut keadilan kepada orang tuanya. (P2.Ka)

b. Subjek mengejek atau menghina adik dan kakaknya. Ejekan subjek dapat tertuju pada mainan milik saudaranya ataupun kondisi fisik saudaranya. (P2.Kb)

c. Subjek merebut barang yang sudah dimiliki oleh saudaranya dengan cara mengambil, menyembunyikan, ataupun membuangnya. (P2.Kc)

d. Subjek dan saudaranya memperebutkan barang yang baru diperoleh. Ketika berebut, subjek selalu ingin mendapatkan barang yang lebih bagus maupun lebih banyak dibandingkan dengan adiknya. (P2.Kd)

e. Subjek dan saudaranya sering saling mengganggu dengan cara berteriak, menyanyi, menarik rambut, maupun merusak telepon genggam. (P2.Ke)

f. Subjek dan saudaranya saling mengucilkan ataupun menolak satu sama lain baik dalam mengajak bermain maupun dalam permainan itu sendiri. (P2.Kf)

g. Suasana hati subjek sering berubah-rubah. Dari awalnya berperilaku buruk kepada adiknya, kemudian tiba-tiba baik, dan kembali berperilaku buruk. (P2.Kg)

Pola 3. Sibling rivalry (P3)

a. Kondisi liburan menyebabkan subjek dan saudaranya menjadi sering bertemu, sehingga mereka bertengkar hampir setiap hari. (P3.Ka) b. Muncul agresi secara fisik ketika subjek bertengkar dengan saudaranya. (P3.Kb)

c. Munculnya agresi secara verbal ketika subjek bertengkar dengan saudaranya. (P3.Kc)

d. Munculnya rivalry ketika subjek bertengkar dengan saudaranya. (P3.Kd)

e. Terjadi ketidakadilan yang dirasakan oleh kakak dan adik subjek, sehingga mereka akan pergi mengadu.(P3.Ke)

f. Saat bertengkar, terkadang subjek mengalah dan lebih memilih diam. Hal ini dikarenakan subjek takut akan membuat ayah dan ibunya marah. (P3.Kf)

g. Subjek menangis tanpa sebab ataupun alasan yang jelas. (P3.Kg)

h. Subjek memilih bengong dan bermain telepon genggam ketika tidak ada teman diajak bermain. Telepon genggam juga menambah kesibukan subjek sehingga frekuensi pertengkaran berkurang. (P3.Kh)

Pola 4. Cara Penyelesaian Masalah Ketika Terjadi Konflik (P4)

a. Ayah subjek cenderung memenangkan subjek dalam pertengkaran. Selain itu ia mengarahkan, menegur dan menasihati kedua saudara subjek untuk menyesuaikan diri mereka kepada subjek (P4.Ka)

b. Ibu subjek keras dan berusaha adil dalam menghukum anaknya, akan tetapi memberi sedikit pengecualian pada subjek. (P4.Kb)

c. Kakak subjek berusaha menyelesaikan masalah adikadiknya dengan cara bersikap tegas dan adil. Akan tetapi jika permasalahan tersebut melibatkannya dan ia terbawa emosi, ia tidak berharap untuk berbaikan.(P4.Kc)

d. Saat memilih saluran televisi, subjek dan saudaranya dapat menyelesaikan permasalahan mereka bersama-sama. (P4.Kd)

Pola 5. Setelah Pertengkaran Selesai (P5)

a. Kakak dan adik subjek merasa tidak mendapat keadilan dan masih mempermasalahkan pertengkaran yang sudah berlalu. (P5.Ka)

b. Setelah bertengkar, subjek akan berperilaku seperti sebelum pertengkaran terjadi. Ia akan mendekati kakaknya dan bertingkah laku seperti biasa. (P5.Kb)

Pola 6. Sudut Pandang Antara Subjek dan Saudaranya (P6)

a. Kakak subjek tidak terlalu memiliki rasa hormat dengan subjek, namun tuntutan dari orang tua yang membuat ia perhatian terhadap subjek. Ia menganggap subjek sebagai sosok yang tidak terlalu mengganggu meski cepat emosi dan marah.(P6.Ka)

b. Kakak subjek menganggap adik subjek adalah sosok yang sangat menyinggung dengan perkataannya. (P6.Kb)

c. Subjek dan adik subjek memperebutkan perhatian dari kakak subjek (P6.Kc) 
d. Subjek lebih takut dengan adiknya ketimbang dengan orang tuanya, karena adiknya lebih tegas dan galak (P6.Kd)

e. Meskipun terlihat emosi dan galak, sebenarnya subjek peduli dengan adiknya. (P6.Ke)

f. Saat subjek melakukan hal berbahaya seperti naik sepeda terlalu jauh sendirian, adik subjek

g. Adik subjek memiliki rasa hormat serta menurut pada kakak subjek. (P6.Kg)

h. Adik subjek memiliki perasaan tidak suka terhadap subjek dan menolak untuk menunjukkan afeksi kepada subjek. Ia menganggap subjek sebagai sosok yang jahat, mengganggu dan menghalangi dirinya. (P6.Kh)

i. Adik subjek lebih suka bermain dengan temannya tanpa mengajak subjek. Teman dari adik subjek mengatakan kepada adik subjek bahwa mereka takut dipukul subjek. (P6.Ki)

j. Subjek sangat suka mandi, biasanya bersama dengan adiknya. (P6.Kj)

\section{PEMBAHASAN DAN KESIMPULAN}

Dinamika sibling rivalry pada anak dengan mild intellectual disability dan saudara kandung terbagi atas 6 pola. Ke 6 pola ini terhubung dalam sebuah proses sibling rivalry yang terjadi pada kasus ini. Pola yang didapat peneliti dalam penelitian ini antara lain faktor-faktor sibling rivalry, pemicu pertengkaran, sibling rivalry, cara penyelesaian masalah ketika terjadi konflik, situasi setelah pertengkaran selesai, dan sudut pandang antara subjek dan saudaranya.

Peneliti menemukan bahwa terjadinya sibling rivalry pada kasus ini dipengaruhi oleh berbagai faktor. Meskipun fokus utama yang disorot peneliti adalah gangguan yang dimiliki subjek, faktor ini terhubung dengan berbagai macam faktor lainnya yang mempengaruhi sibling rivalry. Hal ini menyangkut tentang bagaimana seorang anggota keluarga dalam kasus ini berperilaku terhadap anggota keluarga lainnya. Baik anak dengan mild intellectual disability, saudara, maupun orang tua terhubung dalam suatu proses yang mengkondisikan sibling rivalry berlangsung.

Pada Pola 1 terdapat faktor-faktor yang mengawali sibling rivalry pada anak dengan mild intellectual disability dan saudara kandung. Peneliti menemukan subjek dan saudaranya terlibat dalam perebutan barang-barang seperti pakaian, alat tulis dan alat elektronik. Boyle (2011) mengatakan barang tersebut merupakan sumber daya penyebab konflik antar saudara. Di samping itu, anak dengan mild intellectual disability dan saudaranya juga terlihat berkompetisi di berbagai bidang lainnya, termasuk dalam memperebutkan perhatian orang sekitar, baik orang tua maupun peneliti. Johnson (1993) mengatakan bahwa permainan bagi anak-anak bukan sekedar untuk mendapat kegembiraan, namun merupakan keinginan untuk mengalahkan lawannya.
Pada pola 2 terdapat berbagai situasi yang mengarah ke pertengkaran ditemukan oleh peneliti, seperti ketika berbelanja, berebut barang, mengejek maupun mengganggu satu sama lain. Peneliti menemukan pemicu pertengkaran yang unik dalam penelitian ini adalah suasana hati anak dengan mild intellectual disability yang berubah-ubah. Berek (2011) mengatakan bahwa memang anak dengan intellectual disability memiliki suasana hati yang sering berubah.

Pola 3 menjelaskan bentuk dan gambaran sibling rivalry itu sendiri. Ditemukan bahwa subjek dan saudaranya sering bertengkar, bahkan hampir setiap hari. Pertengkaran ini dapat berbentuk agresi secara verbal maupun non-verbal, selain itu rivalry juga muncul diantara mereka. Peneliti menemukan bahwa dalam situasi tertentu anak dengan mild intellectual disability lebih memilih diam dan mengalah, gejala depresi pun ditemukan pada diri anak dengan mild intellectual disability saat sibling rivalry. Bentuk sibling rivalry yang muncul sesuai dengan bentuk agresi dan rivalry yang dijelaskan oleh Sawicki (1997).

Pola 4 menjelaskan cara penyelesaian masalah. Bindley (2011) mengatakan bahwa normal bagi orang tua dari anak berkebutuhan khusus memiliki pengecualian pada anak tersebut. Baik ayah subjek maupun ibu subjek, ditemukan memiliki beberapa pengecualian untuk subjek saat menyelesaikan masalah. Mereka menyadari gangguan milik subjek memerlukan perlakuan yang berbeda. Sementara kakak subjek menyadari tanggung jawabnya sebagai kakak dan berusaha menyelesaikan masalah bila tidak ada orang tua mereka (Moore, 2014). Di satu sisi dalam situasi tertentu, anak dengan mild intellectual disability dan saudaranya dapat menyelesaikan masalah bersama-sama. Masalah melatih anak dan saudara untuk bernegosiasi dan menyelesaikannya (Bomb, 2005).

Pola 5 menjelaskan situasi setelah suatu pertengkaran terselesaikan. Kakak dan adik subjek tidak dapat menerima penyelesaian begitu saja. Timbul perasaan ketidakadilan pada diri mereka, yang menyebabkan mereka mengadu kepada orang tua, kesal dan menolak subjek. Sementara anak dengan mild intellectual disability sendiri berbeda. IDRS (2014) mengatakan bahwa anak dengan intellectual disability cenderung memiliki kesulitan menginterpretasi situasi sekitarnya. Ditemukan segera setelah pertengkaran selesai subjek akan bertingkah laku seperti biasa sebelum pertengkaran terjadi.

Pola 6 menjelaskan hubungan di antara subjek dan saudaranya. Secara umum, kakak subjek berusaha bersifat adil kepada dua adiknya. Tuntutan dari orang tua membuat kakak dari anak dengan mild intellectual disability menjadi lebih bertanggung jawab, netral, dan adil (Harry, 1992). Anak dengan mild intellectual disability pada kasus ini sering terlihat galak pada adiknya, meskipun sebenarnya peduli. Hal ini sesuai dengan yang dikemukakan oleh AACAP (2004) 
bahwa anak dengan intellectual disability memiliki kesulitan untuk mengendalikan emosinya. Subjek terlihat membagi makanan dan memperhatikan penampilan adiknya. Subjek juga suka mandi bersama dengan adik. Adik subjek cenderung menunjukkan rasa hormat kepada kakaknya yang paling besar, namun tidak suka dengan subjek sendiri. Perasaan tidak suka ini dikarenakan oleh beberapa perlakuan subjek yang tidak disukai adik subjek. Saat adik subjek bermain dengan temannya pun, ia tidak senang dan menghindar jika subjek ingin bergabung di dalamnya. Adik subjek tidak mengerti kondisi gangguan subjek yang menyebabkan subjek berperilaku tidak seperti anak pada normalnya. Adik subjek menganggap bahwa memang subjek sendiri adalah orang yang galak dan jahat. Baik tekanan maupun kebingungan konsep yang dirasakan oleh adik subjek sesuai dengan perasaan yang muncul pada adik dari seorang anak dengan mild intellectual disability menurut Porter dan McKenzie (2000).

Secara umum, terjadi sibling rivalry pada anak dengan mild intellectual disability dan saudara kandung. Keterbatasan anak dengan mild intellectual disability sendiri menjadi keunikan dalam munculnya sibling rivalry pada kasus ini. Contohnya seperti suasana hati subjek yang berubah-ubah sehingga perilaku kepada saudara pun berubah-ubah pula. Kondisi anak dengan mild intellectual disability membuat orang tua memberikan perlakuan berbeda pada dirinya, memberikan tanggung jawab lebih pada kakaknya, dan menimbulkan rasa tidak suka pada diri adiknya.

Penelitian lain yang memiliki karakteristik kasus maupun karakteristik subjek serupa dengan penelitian ini diharapkan menghasilkan hasil yang serupa pula. Sehingga baik kesimpulan maupun saran dari penelitian ini dapat diterapkan dan memberikan manfaat bagi penelitian lainnya.

Adapun saran dari penelitian bagi keluarga dari anak dengan mild intellectual disability agar dapat memberi perhatian baik kepada anak dengan mild intellectual disability sendiri, maupun kepada saudara. Selain itu keluarga juga diharapkan dapat membuat cara penyelesaian masalah bersama yang mengajak seluruh anggota keluarga untuk lebih aktif berpendapat. Bagi penelitian selanjutnya diharapkan dapat memiliki variasi karakteristik anak dengan mild intellectual disability yang berbeda untuk membandingkan hasilnya. Teknik ataupun media untuk membangun rapport dengan subjek disesuaikan dengan karakteristik anak yang didapat. Selain itu juga diharapkan lebih memaksimalkan peran asisten peneliti, sehingga memperoleh sudut pandang yang berbeda.

\section{DAFTAR PUSTAKA}

American Academy of Child and Adolescent Psychiatry (AACAP) (2012). Children with an intellectual disability. Facts for Families.
American Psychiatric Association. (2000). Diagnostic and statistical manual of mental disorders (4th ed., text rev.). Washington, DC: Author Basrowi, \& Suwandi. (2008). Memahami penelitian kualitatif. Jakarta: Rineka Cipta.

Basrowi, \& Suwandi. (2008). Memahami penelitian kualitatif. Jakarta: Rineka Cipta.

Batt, E. (2010). ADHD Negatively impacts a child's relationship with siblings Suite101. Suite101. Diakses 20 Mei 2013, dari http://suite101.com/article/adhd-maynegatively-impact-a-childs-relationships-with-siblingsa228655.

Beck, J. (2003). Williams sisters' impact on tennis becoming apparent. Access My Library. Diakses 1 Juni 2013, dari www.accessmylibrary.com/article-1G1-

98719357/williams- sisters-impact-tennis.html.

Berek, P. E. (2011). Pengaruh terapi bermain terhadap perkembangan motorik halus pada anak retardasi mental di SLB C Negeri II Gondomanan Yogyakarta. Jurnal Ilmu Kesehatan Universitas Respati Yogyakarta.

Bindley, K. (2011). How parents can deal with having a favorite child. Diakses 1 September 2014, dari http://www.huffingtonpost.com/2011/09/21/parents-withfavorite-child_n_972523.html.

Bomb.,P. (2005). Social skills and siblings in India. University of Missouri-Columbia.

Boyle, W. A. (2011). Sibling Rivalry. Angelfire: Welcome to Angelfire. Diakses 20 Mei 2013, dari http://www.angelfire.com/md/imsystem/sibriv1.html.

Braverman, J. (2014). Understanding jealousy in kids. Diakses 10 September 2014, dari http://www.livestrong.com/article/81524-jealousy-kidschildren/.

Burger, J. M. (2008). Personality (7thed.). Belmont: Wadsworth Cengage Learning.

Byron, J. (2011). Cain and Abel in text and tradition Jewish and Christian interpretations of the first sibling rivalry. Leiden : Brill.

Chaudhuri, A. (2008). Impact of sibling rivalry on the nutritional status of children; evidence from matlab, bangladesh. Sibling Rivalry and Child's Health, 16, 28 - 56.

Chung, K.K.H., Tam, Y.H. (2005). Effects of cognitive-based instruction on mathematical problem solving by learners with mild intellectual sabilities. Journal of Intellectual \& Developmental Disability, 30 (4) , 207-216.

Creswell, J. W. (1998). Qualitative inquiry and research design: choosing among five approaches. London: SAGE.

Dacey, J.S., \& Travers, J.F. (1996). Human development : across the lifespan (3rd ed.). Madison, Wis.: Brown \& Benchmark Publishers.

Diament, M. (2010). Obama signs bill replacing 'Mental Retardation' with 'Intellectual Disability'. - Disability Scoop. Diakses 1 Maret 2014, dari http://www.disabilityscoop.com/2010/10/05/obama-signsrosas-law/10547/.

Diagnostic and statistical manual of mental disorders: DSM-IV-TR. (4th ed.). (2000). Washington, DC: American Psychiatric Association. 
Dixon, J. (2012). An examination of experiences of siblings of people with disabilities in new zealand. Siblings with disability,2, $110-118$.

Dunn, J. (1996). Arguing with siblings, friends, and mothers: Developments in relationships and understanding. In D. Slobin, J. Gerhardt, A. Kyratzis, \& J. Guo (Eds.), Social interaction, social context, and language. Mahwah, NJ: Lawrence Erlbaum Associates.

Dunn, J., \& Munn,. P (1985). Becoming a family member : Familiy conflict and the development of social understanding in the second year. Child Development, 56, 480 - 492.

Fatimah, L. (2012). Hubungan pola asuh orang tua dengan perkembangan anak di R.A Darussalam Desa Sumber Mulyo, Jogoroto, Jombang. Skripsi. Fakultas Psikologi. Universitas Pesantren Tinggi Darul Ulum Jombang.

Gardner, W. I. (2007). Aggresion in persons with intellectual disabilities and mental disorders. Handbook of Intellectual and Developmental Disabilities, 4, 541-562. US: Springer.

Garg, A., \& Morduch, J. (1998). Sibling Rivalry and the gender gap; Evidence from child health outcomes in Ghana. Journal of Popular Economics.

Gralfitrisia, A. (2012). Dukungan keluarga dalam merawat anak retardasi mental di slb padangsidimpuan. Skripsi. Fakultas Keperawatan. Universitas Sumatra Utara.

Gresham, F. M., \& MacMillan, D. L. (1997). Social competence and affective characteristics of students with mild disabilities. Review of Educational Research, 67, 377-415.

Gunter, B., \& Furnham, A. (1998).Children as consumers : A psychological analysis of the young people's market. London: Psychology Press.

Hadibroto, I., Alam, S., Suryaputra, E., \& Olivia, F. (2002). Misteri perilaku anak sulung, tengah, bungsu,tunggal. Jakarta: PT Gramedia Pustaka Utama.

Harry, B. (1992). Making sense of disability: Low-income, Puerto Rican parents' theories of the problem. Exceptional Children, 59 (1), 27-40.

Hartley, S.L., MacLean, M.E. (2007). Staff-averse challenging behaviour in older adults with intellectual disabilities. Journal of Applied Research on Older Adults with Intellectual Disabilities, 20(6),519-528.

Hidayat, T. (2004). Sudah dewasa, tetapi masih seperti anak SD [Online]. Diakses 1 Juni 2013, dari pikiran-rakyat.com.

Hurlock, E. (1989). Perkembangan anak Jilid 2. Jakarta:Erlangga.

Hurlock, E. (1980). Psikologi perkembangan : Suatu pendekatan sepanjang rentan kehidupan edisi kelima. Jakarta: Erlangga.

IMDB (2013). Rain Man (1988) - IMDb. IMDb - Movies, TV and Celebrities. Diakses 2 Juli 2013, dari http://www.imdb.com/title/tt0095953/.

Intellectual Disability Right Service (IDRS) (2014). Possible links between disability and charges. Diakses 1 September 2014, dari http://www.idrs.org.au/s32/ _guide/p090_2_1_quickReference.php.

Johnson, C.E. (1993). Children and competition. North Carolina Cooperative Extension Service.

Klein, S. D., \& Schleifer, M. J. (1993). It isn't fair! siblings of children with disabilities. Westport, Conn.: Bergin \& Garvey.
Leder, J. M. (2004). Adult sibling rivalry. Psychology today: health, help, happiness + find a therapist. Diakses 25 Mei 2013, dari http://www.psychologytoday.com /articles/pto19930101-000023.html.

Leifer, A.D., N.J.Gordon, S.B. Graves (1974). Children's television : More than mere entertainment. Harvard Educational Review, 44, 213-245.

Listiani, I. (2010). Penyebab terjadinya sibling rivalry pada anak usia sekolah di RW 9 kelurahan Jomblang kota Semarang. Skripsi. Fakultas Keperawatan. Universitas Muhammadiyah Semarang.

Lumbantobing, S.M. (2001). Anak dengan mental terbelakang. Jakarta: Balai Penerbit FKUI.

Macklem, G.L. (2003). Bullying and teasing : SocialpPower in children's groups. Springer Science \& Business Media.

Maulina, B., \& Sutatminingsih, R. (2005). Stres ditinjau dari harga diri pada ibu yang memiliki anak penyandang retardasi mental. Psikologia, 1(1).

Moleong, L. J. (2004). Metodologi Penelitian Kualitatif. Bandung: PT Remaja Rosdakarya.

Moore, A. (2014). The effects of an older sibling taking care of a younger sibling. Livestrong. Diakses 4 September 2014, dari http://www. livestrong.com/article/543273-the-effectsof-an-older-sibling-taking-care-of-a-younger-sibling/.

Morduch, J. (2000). Sibling rivalry in Africa. The American Economic Review,90(2).

Mulyono, A. (1999). Pendidikan bagi anak berkesulitan belajar. Jakarta: Rineka Cipta Kota

Mumpuniarti (2007). Pendekatan pembelajaran bagi anak dengan hambatan mental. Yogyakarta: Kanwa Publisher.

Nitsch, A., Faurie, C., \& Lummaa, V. (2013). Are elder siblings helpers or competitors? Antagonistic fitness effects of sibling interactions in humans. Proceedings of Royal Society, 1, 280.

Noviani (2010). Gambaran pengetahuan orang tua tentang sibling rivalry pada anak usia pra sekolah. Jurnal Psikologi Universitas Muhammadiyah Malang.

Ostrov, J., Crick, N., \& Stauffacher, K. (2006). Relational aggresion in sibling and peer relationships during early childhood. Journal of Applied Developmental Psychology, 27(3), 241253.

Papalia, D. E., Olds, S. W., \& Feldman, R. D. (2009). Human development. New York: McGraw Hill.

Pendley, J. S. (2012). Sibling rivalry. KidsHealth - the Web's most visited site about children's health. Diakses 9 Mei 2013, dari http://kidshealth.org/parent /positive/family/sibling_rivalry.

Poerwandari, E. K. (1998). Pendekatan kualitatif dalam penelitian psikologi. Jakarta: LPSP3.

Porter, L.\& McKenzie, S. (2000). Siblings of children with disabilities. Professional collaboration with parents of children with disabilities. London, Wiley.

Powell, T. \& Gallagher, P. (1993). Brothers and sisters: A special part of exceptional families. (2nd ed.) Baltimore, MD: Paul H. Brookes.

Rabiner, D. (2006). The impact of adhd on siblings. Diakses 2 Maret 2014, dari http://www.helpforadd.com/add-impact-onsiblings/. 
Rauer,A.J. \& Volling, B.L. (2007). Differential parenting and sibling jealousy: Developmental correlates of young adult's romantic relationships. Personal Relationships, 14(4), 475511 .

Recchia, H. E., \& Howe, N. (2009). Associations between social understanding, sibling relationship quality, and siblings conflict strategies and outcomes. Child Development, 80(5), 1564-1578.

Rimm, S. B. (2002). The effects of siblings competition. Gifted Children, Parenting, Creativity Tests, and Underachievement Reversed: Dr. Sylvia Rimm. Diakses 12 Mei 2013, dari http://www.sylviarimm.com/.

Rocker, L. (2010). Sibling rivalry. Diakses 29 Agustus 2014, dari http://childpsychologist. com.au /resources/sibling-rivalry.

Salmiah, S. (2010). Retardasi mental. Jurnal Fakultas Kedokteran Gigi Univeresitas Sumatera Utara.

Sawicki, J. A. (1997) "Sibling rivalry and the new baby: anticipatory guidance and management strategies." Pediatric Nursing.

Setiawati, Zulkaida, A.(2007). Sibling rivalry pada anak sulung yang diasuh single father. Proseding Pesat.

Shaffer, D.R. (2002). Childhood and adolescence : Developmental psychology. (6th ed.). USA : Wadsworth Group.

Shaw-Smith, C.,Redon, R., Rickman, L., Rio M., Willatt L., Fiegler H., dkk. (2004). Microarray based comparative genomic hybridization (array-CGH) detects submicroscopic chromosomal deletions and duplications in patients with learning disability/mental retardation and dysmorphic features. Journal of Medical Genetics, 41, 241-248.

Straus, M.A., Gelles, R.J., Steinmetz, S.K. (2006). Behind closed doors : Violence in the american family. Transaction Publisher.

Strauss, A., Corbin, J. (2003). Dasar-dasar penelitian kualitatif (Kamdani ed.). (M. Shodiq, \& I. Muttaqien, Trans.) Yogyakarta: Pustaka Pelajar.

Sugiyono. (2012). Metode penelitian kuantitatif, kualitatif, dan R\&D. Bandung: Alfabeta.

Sulloway, F.J., (2012). Birth order, sibling competition and human behaviour. Journal of Psychology University of California, Berkeley.

Teti, D.M., and Ablard,K.E. (1989). Security of attachment and infant sibling relationships : A laboratory Study. Child Development, 60, 19-28.

Teven, J., Martin, M., \& Neupaue, N. (2009). Sibling relationships: Verbally aggressive messages and their effect on relational satisfaction. Communication reports, 11, 179-186.

Thompson, J.A. (2004). Implicit belief about relationships impact the sibling jealousy experience. theses. North Carolina State University.

Tsibidaki, A. (2012). Children with mild intellectual disability represent their family. Advanced Research in Scientific Area.

Van der Molen, M.J.,,Van Luit J. E. H., Jongmans M.J., (2006) Verbal working memory children with mild intellectual disabilities. Journal of Intellectual Disabilities Research, 51, 162-169.

Van de Vliet, P., Rintala, P., Fröjd, K., Verellen, J.,Van Houtte, S., Daly, D.J., dkk. (2005). Physical fitness profile of elite athletes with intellectual disability. Scandinavian Journal of Medicine \& Sports, 16, 417-425.

Vuijk, P.J., Hartman, E., Scherder, E., Visscher, C. (2010). Motor performance of children with mild intellectual disability and borderline intellectual functioning. Journal of Intellectual Disabilities Research, 54, 955-965.

Wahab, R.,(2005). Country report on education provisions for the childlren with intellectual disabilities in indonesia. Ministry of National Education Republic of Indonesia. Diakses 28 Agustus 2013, dari www.idrs.org.au/education/aboutintellectual-disability.php.

Weiner, I.B., Freedheim, D.K. (2003). Handbook of psychology, developmental psychology. London: John Wiley \& Sons.

Weiss, T. C. (2013). Sibling rivalry: What is it and why does it happen. Disabled World. Diakses 26 Agustus 2014, dari http://www.disabled-world.com/disability/children /siblingrivalry.php.

Wen, R. Australian Institute of Health and Welfare Canberra (1997). The definition and prevalence of intellectual disability in Australia.

Woolfson R. C.(2003). Persaingan saudara kandung. London, Octopus Publishing Group. 